This item was submitted to Loughborough's Research Repository by the author.

Items in Figshare are protected by copyright, with all rights reserved, unless otherwise indicated.

\title{
Producing and responding to -isms in interaction
}

PLEASE CITE THE PUBLISHED VERSION

http://dx.doi.org/10.1177/0261927X15586432

\section{PUBLISHER}

Sage Publications / @ The Authors

\section{VERSION}

AM (Accepted Manuscript)

\section{PUBLISHER STATEMENT}

This work is made available according to the conditions of the Creative Commons Attribution-NonCommercialNoDerivatives 4.0 International (CC BY-NC-ND 4.0) licence. Full details of this licence are available at: https://creativecommons.org/licenses/by-nc-nd/4.0/

\section{LICENCE}

CC BY-NC-ND 4.0

\section{REPOSITORY RECORD}

Stokoe, Elizabeth. 2019. "Producing and Responding to -isms in Interaction". figshare. https://hdl.handle.net/2134/17536. 


\section{Producing and Responding to -isms in Interaction}

Kevin A. Whitehead ${ }^{\mathrm{i}}$

Elizabeth Stokoe ${ }^{\text {ii }}$

\footnotetext{
${ }^{\mathrm{i}}$ University of the Witwatersrand, Johannesburg, South Africa

${ }^{\text {ii }}$ Loughborough University, Loughborough, UK
}

\section{Corresponding Author:}

Kevin A. Whitehead, Department of Psychology, University of the Witwatersrand, Private Bag 3, P.O. Wits, 2050, South Africa

E-mail: kevin.whitehead@wits.ac.za 


\begin{abstract}
We provide an introduction to some of the conceptual and methodological debates with respect to the focus of this special issue on-isms (a term used to refer to phenomena such as racism, sexism, and heterosexism), focusing on the definition and identification of these phenomena. We offer an overview of the different approaches to research in this regard, and conclude by summarizing the contributions to this special issue.
\end{abstract}

\title{
Keywords
}

Racism, sexism, heterosexism, discursive psychology, membership categorization, conversation analysis 
Social scientists have had a longstanding engagement with the collection of social issues known as -isms, a term used to refer to phenomena including sexism, racism, heterosexism, and the like. In the discussion that follows, we situate the contributions to this special issue in the context, firstly, of debates around definitions and identification of -isms and, secondly, with respect to existing research on responses to -isms.

\section{Defining and Identifying -isms}

Scholarship on -isms has been characterized by contentious debates about how they should be defined conceptually. Early definitions (e.g., Benedict's 1942 definition of racism) focused on individual beliefs, setting the scene for the dominance of social psychological approaches that treat prejudice as a defining feature and necessary condition for their identification (e.g., Dovidio \& Gaertner, 2004; Sears, Van Laar, Carrillo, \& Kosterman, 1997). In part as a result of methodological difficulties in detecting and measuring prejudice, researchers turned further inward in search of a "core" of prejudice beyond the intentional control or awareness of the individuals concerned. Notwithstanding the continuing popularity of this social cognitive approach, definitions that give a central place to essentially individual psychological aspects of -isms have been criticized for reducing them to individual pathologies at the expense of attending to their structural or institutional features (see, for example, Bonilla-Silva, 1997; Kitzinger \& Perkins, 1993). In some cases these criticisms have provided the basis for advocating definitions that emphasize how, once established, social-structural arrangements can provide the basis for unequal outcomes even in the absence of prejudice (e.g., Bonilla-Silva, 1997; Carr, 1997). Such definitions have, however, been criticized in turn for neglecting or dismissing the importance of social psychological factors in understanding -isms (e.g., Berard, 2008, 2010). 
In light of the apparent intractability of these debates, researchers working within the discursive psychological tradition have turned their attention to the nature of contestations around both general meanings of -isms, as well as efforts to identify specific instances thereof, not just among academic researchers, but also ordinary people going about their daily business. This research thus respecifies the definitional debates described above as participants' rather than analysts' concerns (cf. Edwards, 2003), examining the ways in which speakers interactionally negotiate and contest what counts as prejudiced, racist, sexist, and so on (e.g., Durrheim, Greener, \& Whitehead, in press; Hastie \& Cosh, 2013).

\section{Research on Responses to -isms}

A further body of work on responses to -isms has examined responses both at the individual or psychological (or "micro") and the structural or institutional (or "macro") levels, while focusing largely on formal, pre-planned interventions. At the "micro" level, a number of studies have examined interventions aimed at raising individual awareness or increasing sensitivity, including general interventions designed to provide "diversity training", "multicultural awareness" and the like (e.g., Kulik \& Roberson, 2008), as well as interventions focusing on particular categories, such as race (e.g., Miller \& Donner, 2000) or gender (e.g., Andrews \& Ridenour, 2006).

Interventions based on the social psychological theorizing and research described above have focused more specifically on bringing about reductions in psychological prejudice (see Paluck \& Green, 2009 for a recent review of research on prejudice reduction interventions). In particular, following the development of implicit measures of prejudice, interventions have been designed inhibit or eliminate the implicit or unconscious biases that are assumed to underpin discriminatory behavior (e.g., Dasgupta \& Greenwald, 2001; Kawakami, Dovidio, Moll, Hermesen, \& Russin, 2000). A consequence of these approaches 
is a focus on individuals as the assumed source of -isms and the site for interventions to address them. This draws attention away from the social contexts of their expression and, consequently, denies researchers the possibility of examining how they may be responded to and/or challenged in the situated moments in which they are produced.

At the "macro" level, interventions are designed to address social-structural or institutional arrangements that serve to produce unequal outcomes for members of different categories, such that some categories (e.g., white, male, heterosexual) are systematically advantaged relative to others (e.g., black, female, gay and lesbian). Research on social movements has examined collective mobilizations that have targeted discriminatory legislation and government policies, including the U.S. civil rights movement (e.g., Omi \& Winant, 1994), South Africa's anti-apartheid movements (e.g., Seekings, 2000), feminist movements (e.g., Charles, 2000), and LGBTI movements (e.g., Kollman \& Waites, 2009). The scope and focus of such movements can range from local government, community or organizational levels to national and international or transnational mobilizations. A number of studies have also examined government-led interventions, such as South Africa's Truth and Reconciliation Commission, in the wake of systematic human abuses in which the category membership of victims was a basis for their victimization, with the aims of revealing the nature of abuses and promoting reconciliation between victims and perpetrators (e.g., Bozzoli, 1998; Motsemme, 2004).

While offering important accounts of the workings of collective responses to-isms, this research (like the micro-level research described above) is ill-equipped to examine situated everyday responses to -isms in the moment-by-moment interactional context of their production. In contrast, research using discursive psychological, conversation analytic, and other discourse analytic approaches is well-suited to offering this type of fine-grained analysis. Research in these traditions has provided detailed accounts of the collaborative 
production of "prejudiced" talk without relying on a methodologically troublesome assumption of the centrality of "inner" psychological prejudice, thereby demonstrating links between such talk and broader ideological and social-structural features (see, e.g., Augoustinos \& Every, 2007; Speer, 2002; Speer \& Potter, 2000). However, this work has paid less attention to how -isms can be responded to by the recipients for whom they are produced, and particularly how they can be resisted or challenged. It is this gap in the litertature that the contributions to this special issue address.

\section{Contributions to (and of) the Special Issue}

The five contributions to this Special Issue engage with the matters discussed above by examining naturally occurring interactional exchanges in which-isms are observably at stake. This provides for a focus on how participants treat (or do not treat) potentially racist, sexist, etc. utterances as such, rather than relying on a priori definitions as a means of authoritatively (from an analyst's perspective) identifying them (cf. Schegloff, 1997).

The use of naturally occurring data and the discourse and conversation analytic approaches employed by the authors allow for detailed analysis of the moment-by-moment unfolding of interactional sequences in which -isms are interactionally produced and responded to. Taken together, the authors' analyses demonstrate some ways in which generic interactional practices that have long been recognized by conversation analysts play a constitutive role with respect to these phenomena, and serve as centrally important resources for participants. Whitehead's analysis demonstrates how features of preference organization can serve as resources for responding to instances of possible racism, as well as providing resources for speakers of racially problematic actions to recognize and repair the problematic aspects of their actions. Robles and Weatherall both examine how aspects of the organization of repair feature in the production of and responses to racism and sexism respectively, while 
Robles also considers the use of extreme case formulations as a mechanism for challenging racist utterances and providing opportunities for speakers to perform repair work on them. Stokoe shows how mediators in neighborhood disputes can either implicitly resist -isms (by sequentially deleting them using reformulations) or explicitly challenge them (by, for example, admonishing speakers who have produced them), and discusses the implications of these findings for applied practice in training mediators using communication training workshops. Finally, Romaniuk examines "meta-sexist" talk, examining the ways in which responses to -isms (in the form of accusations of sexism) are in turn responded to, showing how both antangonistic and acquiescent responses can serve to undermine the legimitmacy of the complaints to which they are responding.

These analyses thus demonstrate some features of how participants "do" (anti)racism, (anti)sexism, and so on, in situated interactions. In the process, like other discursive research in these domains, they offer a way of breaking down the micro-macro binary by showing how structural (macro) features of -isms can become relevant, and thereby come to be reproduced and (on occasion) resisted, in specific (micro) interactional exchanges. While there remains much work to be done in this area, we hope that this special issue will contribute to the stimulation of productive new lines of inquiry.

\section{Acknowledgments}

We would like to thank the JLSP editor, Howard Giles, for his generous facilitation of this Special Issue.

\section{Authors' Note}


An earlier version of the argument presented in this paper served as the abstract for a panel at the $4^{\text {th }}$ International Conference on Conversation Analysis (ICCA-14) in Los Angeles in June 2014

\section{Declaration of Conflicting Interests}

The authors declared no potential conflicts of interests with respect to the authorship and/or publication of this article.

\section{Funding}

The authors received no financial support for the research and/or authorship of this article.

\section{References}

Andrews, M. L., \& Ridenour, C. S. (2006). Gender in schools: A qualitative study of students in educational administration. The Journal of Educational Research, 100, 35-43.

Augoustinos, M., \& Every, D. (2007). The language of "race" and prejudice: A discourse of denial, reason, and liberal-practical politics. Journal of Language and Social Psychology, 26, 123-141.

Benedict, R. (1942). Race and Racism. London, UK: Routledge.

Berard, T. J. (2008). The neglected social psychology of institutional racism. Sociology Compass, 2, 734-764.

Berard, T. J. (2010). Unpacking "institutional racism": Insights from Wittgenstein, Garfinkel, Schutz, Goffman, and Sacks. Schutzian research: A yearbook of lifeworldly phenomenology and qualitative social science (pp. 111-135). Bucharest, Romania: Zeta Books. 
Bonilla-Silva, E. (1997). Rethinking racism: Toward a structural interpretation. American Sociological Review, 62, 465-480.

Bozzoli, B. (1998). Public ritual and private transition: The truth commission in Alexandra township, South Africa 1996. African Studies, 57, 167-195.

Carr, L. G. (1997). "Color-blind" racism. Thousand Oaks, CA: Sage.

Charles, N. (2000). Feminism, the state and social policy. Basingstoke, UK: Macmillan.

Dasgupta, N., \& Greenwald, A. G. (2001). On the malleability of automatic attitudes:

Combating automatic prejudice with images of admired and disliked individuals. Journal of Personality and Social Psychology, 81, 800-814.

Dovidio, J. F., \& Gaertner, S. L. (2004). Aversive racism. In M. P. Zanna (Ed.), Advances in experimental social psychology (pp. 1-52). San Diego, CA: Academic Press.

Durrheim, K., Greener, R., \& Whitehead, K. A. (in press). Race trouble: Attending to race and racism in online interaction. British Journal of Social Psychology.

Edwards, D. (2003). Analyzing racial discourse: The discursive psychology of mind-world relationships. In H. van den Berg, H. Houtkoop-Steenstra \& M. Wetherell (Eds.), Analyzing race talk: Multidisciplinary approaches to the interview (pp. 31-48). Cambridge, UK: Cambridge University Press.

Hastie, B., \& Cosh, S. (2013). "What's wrong with that?" Legitimating and contesting gender inequality. Journal of Language and Social Psychology, 32, 369-389.

Kawakami, K., Dovidio, J. F., Moll, J., Hermesen, S., \& Russin, A. (2000). Just say no (to stereotyping): Effects of training in the negation of stereotypic associations on stereotypic activation. Journal of Personality and Social Psychology, 78, 871-888.

Kitzinger, C., \& Perkins, R. (1993). Changing our minds: Lesbian feminism and psychology. London, UK: Onlywomen Press. 
Kollman, K., \& Waites, M. (2009). The global politics of lesbian, gay, bisexual and transgender human rights: An introduction. Contemporary Politics, 15, 1-17.

Kulik, C. T., \& Roberson, L. (2008). Common goals and golden opportunities: Evaluations of diversity education in academic and organizational settings. Academy of Management Learning and Education, 7, 309-331.

Miller, J., \& Donner, S. (2000). More than just talk: The use of racial dialogues to combat racism. Social Work with Groups, 23, 31-53.

Motsemme, N. (2004). The mute always speak: On women's silences at the Truth and Reconciliation Commission. Current Sociology, 52, 909-932.

Omi, M., \& Winant, H. (1994). Racial formation in the United States: From the 1960s to the 1990s. New York, NY: Routledge.

Paluck, E. L., \& Green, D. P. (2009). Prejudice reduction: What works? A review and assessment of research and practice. Annual Review of Psychology, 60, 339-367.

Schegloff, E. A. (1997). Whose text? Whose context? Discourse and Society, 8, 165-187.

Sears, D. O., Van Laar, C., Carrillo, M., \& Kosterman, R. (1997). Is it really racism?: The origins of white Americans' opposition to race-targeted policies. Public Opinion Quarterly, 16-53.

Seekings, J. (2000). The UDF: A history of the United Democratic Front in South Africa, 1983-1991. Oxford, UK: James Currey Publishers.

Speer, S. A. (2002). Sexist talk: Gender categories, participants' orientations and irony. Journal of Sociolinguistics, 6, 347-377.

Speer, S. A., \& Potter, J. (2000). The management of heterosexist talk: Conversational resources and prejudiced claims. Discourse and Society, 11, 543-572.

\section{Author Biographies}


Kevin Whitehead is an Associate Professor in the Department of Psychology at the University of the Witwatersrand, Johannesburg. His research focuses on the development of an ethnomethodological, conversation analytic approach to examining race and other categorical forms of social organization and inequality. In particular, he is interested in the ways in which racial and other social categories are used, reproduced and resisted in talk-ininteraction.

Elizabeth Stokoe is Professor of Social Interaction in the Department of Social Sciences at Loughborough University, UK. Her current research interests are in conversation analysis, membership categorization, and social interaction in various ordinary and institutional settings, including neighbour mediation, police interrogation, role-play and simulated interaction. She is the co-author of Discourse and Identity (with Bethan Benwell, Edinburgh University Press, 2006) and co-editor of Conversation and Gender (with Susan Speer, Cambridge University Press, 2011). 